\title{
Impact of Serum Granulocyte-Macrophage Colony-Stimulating Factor Levels among Diabetes Patients in Hilla City - Iraq
}

\author{
Alaa Tareq Shakir Al-Hassnawi ${ }^{1}$, Azhar Omran Lattef Al-Thaheb ${ }^{1}$, \\ Hussein Oleiwi Muttaleb Al-Dahmoshi ${ }^{1, *}$, Raheem Toma Al-Mammori \\ Hasanain Khaleel Al-Shareef ${ }^{3}$, Noor Salman Kadhim Al-Khafaji ${ }^{1}$ \\ ${ }^{1}$ Babylon University-College of Science, Biology Department, Iraq \\ ${ }^{2}$ Merjan Medical City, Merjan Hospital-Central Laboratory, Iraq \\ ${ }^{3}$ Babylon University- College of Science for Women, Biology Department, Iraq
}

\begin{abstract}
Background: Granulocyte-macrophage colony-stimulating factor (GM-CSF) is a pro-inflammatory cytokine with growth factor-like properties for monocytes and dendritic cells. Methods: Study subjects were recruited from the hospital in Hilla city. Healthy controls $(n=15)$ and D.M. patients $(n=35)$ were included in the study. Serum levels of GM-CSF and Anti-Insulin Antibody (AIA) measured by using ELISA technique. Results: The serum GM-CSF levels were significantly higher among diabetes subjects as compared with subjects without diabetes and results showed a high significant in serum AIA and glucose levels in patient as compare with control ( $\mathrm{p}=0.009, \mathrm{P}=0.001)$. The serum GM-CSF levels were increased in age group (45-54 years) shows the higher percent (42.85\%) of patients with diabetes, with decreased of AIA and GM-CSF level rather than other age groups. Conclusions: There is indirect relationship between AIA and GM-CSF level and that is mean increased AIA and glucose level reflect the reduced GM-CSF level among the diabetic patients may be used as biomarker or use GM-CSF as co-therapy with insulin.
\end{abstract}

Keywords AIA, GM-CSF, Diabetes Mellitus

\section{Introduction}

Granulocyte-macrophage colony-stimulating factor (GM-CSF) is frequently used in preclinical and clinical protocols to modulate autoimmune responses, bone marrow transplants, and recovery from immune ablative therapies [1].

GM-CSF was originally defined as hemopoietic growth factor. It was involved in regulating the numbers and function of macrophage lineage populations and have been shown to contribute to macrophage heterogeneity [2]. However, it can act on macrophage populations and are implicated in host defense and inflammation [3]. GM-CSF can generate a population of Granulocyte Monocyte- bone marrow-derived macrophages (GM-BMM) $[4,5]$ that have macrophage and dendritic cell (DC) properties and are often employed as a model for an immature DC [6, 7].

In the circumstance of immunity and inflammation, macrophage populations express polarized functions

* Corresponding author:

dr.dahmoshi@yahoo.com (Hussein Oleiwi Muttaleb Al-Dahmoshi) Published online at http://journal.sapub.org/als

Copyright (C) 2014 Scientific \& Academic Publishing. All Rights Reserved depending on their milieu. Mirroring the Th1/Th2 nomenclature, polarized macrophages are often referred to as M1 (classical activation) and M2 (alternative activation) cells, respectively $[8,9]$.

The directed loss of insulin-producing $\beta$-cells by cell mediated autoimmune responses results in insulin dependent diabetes mellitus (IDDM). The non-obese diabetic mouse (NOD) develops diabetes spontaneously and is an important animal model because its pathology resembles that of human IDDM patients. In these mice, the destruction of the $\mathrm{g}$-cells is preceded by inflammatory infiltrates of macrophages and dendritic cells (DC) followed by $T$ and $B$ cells into the pancreatic islets [10]. Although female and male NOD mice develop insulitis, females suffer more invasive and destructive insulitis, leading to a higher incidence of diabetes as compared with males. The development of autoimmune diabetes is T cell mediated and requires the participation of both CD4+ and CD8+ subsets [11].

Autoreactive $\mathrm{T}$ cells recognize antigen in the pancreatic lymph nodes $(\mathrm{pLN})$ and their efficient activation and expansion lead to the development of the disease [12]. Initially, the response is limited to a small number of epitopes within a few proteins but later spreads to other 
determinants, eventually involving $\mathrm{T}$ cells of many specificities [13]. Thus, the presentation of self-islet antigens to autoreactive cells is one of the critical functions underlying the outcome of disease. The priming of autoreactive $\mathrm{T}$ cells is carried out by antigen-presenting cells (APC) including B cells, macrophages, and DC that are themselves responsive to growth factors such as granulocyte-monocyte colony-stimulating factor (GM-CSF) [14]. Judkowski et. al. [1] results indicate that GM-CSF enhanced disease in male NOD mice by triggering APC recruitment and high levels of self antigen presentation. GM-CSF reduces the threshold for induction of pathogenic $\beta$-cell autoreactivity in susceptible mice.

\section{Material and Method}

\section{Enzyme Linked ImmunoSorbent Assay (ELISA):}

The detection GM-CSF and AIA in serum by using enzyme linked immuno-sorbent assay (ELISA). In present study the quantitative GM-CSF ELISA kit (Bosterbio/USA) and AIA ELISA kit (Asculab/Germany) tested by ELISA system (BioTeck/USA) the basic assay steps as follow:

1. Aliquot $0.1 \mathrm{ml}$ per well of the $1000 \mathrm{pg} / \mathrm{ml}, 500 \mathrm{pg} / \mathrm{ml}$, $250 \mathrm{pg} / \mathrm{ml}, 125 \mathrm{pg} / \mathrm{ml}, 62.5 \mathrm{pg} / \mathrm{ml}, 31.2 \mathrm{pg} / \mathrm{ml}, 15.6 \mathrm{pg} / \mathrm{ml}$ of standard solutions were added into the precoated 96-well plate. Addition of $0.1 \mathrm{ml}$ of the sample diluent buffer into the control well (Zero well). Addition $0.1 \mathrm{ml}$ of each properly diluted sample of human serum to each empty well.

2. Sealing of the plate with the cover and incubation at $37^{\circ} \mathrm{C}$ for $90 \mathrm{~min}$.

3. Removing of the cover, discard plate content, and bloting the plate onto paper towels or other absorbent material.

4. Addition of $0.1 \mathrm{ml}$ of biotinylated anti-human GM-CSF (or AIA) antibody working solution into each well and incubate the plate at $37^{\circ} \mathrm{C}$ for $60 \mathrm{~min}$.

5. Washing plate 3 times with $0.01 \mathrm{M}$ TBS or $0.01 \mathrm{M}$ PBS, and each time let washing buffer stay in the wells for 1 min. Discard the washing buffer and blot the plate onto paper towels or other absorbent material.

6. Addition of $0.1 \mathrm{ml}$ of prepared $\mathrm{ABC}$ working solution into each well and incubation of the plate at $37^{\circ} \mathrm{C}$ for $30 \mathrm{~min}$.

7. Washing plate 5 times with $0.01 \mathrm{M}$ TBS or $0.01 \mathrm{M}$ PBS, and each time let washing buffer stay in the wells for 1-2 min. Discard the washing buffer and blot the plate onto paper towels or other absorbent material.

8. Addition of $90 \mu \mathrm{l}$ of prepared TMB color developing agent into each well and incubate plate at $37^{\circ} \mathrm{C}$ in dark for 15-20 min.

9. Addition of $0.1 \mathrm{ml}$ of prepared TMB stop solution into each well. The color changes into yellow immediately.

10. Reading the O.D. absorbance at $450 \mathrm{~nm}$ in a microplate reader within $30 \mathrm{~min}$ after adding the stop solution.
Subjects: Thirty five patients with Diabetes Mellitus were included in this study during their visiting of Diabetic Center in Hilla Teaching Hospital. The diagnosis was made by specialized Physician and to evaluate the positive and negative result, blood samples were obtained from the patients and control groups in the morning.

Control group: consisted of 15 healthy volunteers. They were evaluated to rule out any medical and psychiatric disorders.

\section{Glucose measurement:}

Glucose levels was measured by Reflotron plus (Roch/Germany).

\section{Statistical Analysis}

All statistical analyses were performed using SPSS 10.0 statistical software (SPSS Inc., Chicago, USA). Descriptive statistics were shown in either mean \pm standard deviation notation or as frequency tables. Relations among the categorical variables were investigated by LSD. P-values less than or equal to 0.05 were considered statistically significant.

\section{Serum Collection}

$5 \mathrm{ml}$ of blood was obtained from each of patient and healthy subject by venipuncture, under sterile conditions. Serum was separated from whole blood by centrifugation at 1000 r.p.m. and was stored at $-20^{\circ} \mathrm{C}$ until use. Lysed cells were centrifuged at $12000 \mathrm{~g}$ f or 1 hour at $4^{\circ} \mathrm{C}$.

\section{Result}

\section{GM-CSF and Anti -Insulin Antibody (AIA):}

Our data has revealed a significantly decreasing in GM-CSF concentration $(\mathrm{P}=0,02)$ among diabetic patients as compare with control, whereas, a significantly $(\mathrm{P}=0.009)$ anti insulin antibody (AIA) concentration increased (table 1).

Table (1). Concentration in mean $\pm \mathrm{S} . \mathrm{D}(\mathrm{pg} / \mathrm{ml})$ of Anti insulin antibody and GM-CSF among diabetic patients and control

\begin{tabular}{|c|c|c|c|}
\hline Groups & Test. & Control & P. Value \\
\cline { 1 - 3 } P. Number & 35 & 15 & \multirow{2}{*}{0.02 (S.) } \\
\cline { 1 - 3 } $\begin{array}{c}\text { Mean } \pm \text { SD } \\
\text { GM-CSF }\end{array}$ & $118.39 \pm 39.46$ & $517.7 \pm 172.56$ & 0.009 (H.S.) \\
\cline { 1 - 3 } $\begin{array}{c}\text { Anti Insulin } \\
\text { Ab.(AIA) }\end{array}$ & $6.781 \pm 2.26$ & $2.046 \pm 0.682$ & 0.001 H.S. \\
\hline G. Level & $205 \pm 68.6$ & $94.9 \pm 31.64$ & \\
\hline
\end{tabular}

Our investigation revealed the significant effect of the age interval groups (table 2) in Concentration in mean \pm S.E of anti-insulin $\mathrm{Ab}$. and GM-CSF, where Post hoc analysis by using $\operatorname{LSD}(4.5,74.7)$ especially among $15-24$ years and $>$ 65 year old. The highest percentage of age are group ( 45 -54 year) have $42.85 \%$, while other age groups in less percent. 
Table (2). Concentration in mean $\pm \mathrm{S} . \mathrm{E}(\mathrm{pg} / \mathrm{ml})$ of anti-insulin Ab. And GM-CSF in different age groups

\begin{tabular}{|c|c|c|c|c|}
\hline \multicolumn{2}{|c|}{ Groups } & No. (\%) & Anti insulin $A b$. & $G M-C S F$ \\
\hline \multirow{6}{*}{$\begin{array}{l}\text { Age range } \\
\text { (year) }\end{array}$} & $15-24$ & $1(2.85 \%)$ & 1.97 & 105.5 \\
\hline & $25-34$ & $2(5.71 \%)$ & 7.8 & 104.2 \\
\hline & $35-44$ & $12(34.28 \%)$ & 8.09 & 102.7 \\
\hline & $45-54$ & $15(42.85 \%)$ & 7.15 & 99.7 \\
\hline & $55-64$ & $3(8.57 \%)$ & 5.28 & 123.7 \\
\hline & $>65$ & $2(5.71 \%)$ & 2.58 & 361 \\
\hline \multicolumn{3}{|c|}{ LSD ( Test groups and control ) } & 4.5 & 74.7 \\
\hline
\end{tabular}

The table (3) shows that the result of glucose level of diabetes mellitus patients, beginning from $100 \mathrm{mg} / \mathrm{dl}$ up to $350 \mathrm{mg} / \mathrm{dl}$ arranged in class interval at $50 \mathrm{mg} / \mathrm{dl}$, the glucose level lying in between $151-200,201-250 \mathrm{mg} / \mathrm{dl}$ have major groups of patients at $37.14 \%$ and $28.57 \%$ respectively, while other groups in less percent. The lowest G. level is associated with lowest AIA and GM-CSF level in comparison with other groups as well as highly glucose concentration $(>300 \mathrm{mg} / \mathrm{dl})$ was associated with lower AIA level in comparison with other groups and control samples.

Table(3). Anti insulin Ab. and GM-CSF concentration levels among different intervals glucose levels

\begin{tabular}{|c|c|c|c|c|}
\hline \multicolumn{2}{|c|}{ Groups } & No. (\%) & Anti Insulin Ab. & GM-CSF \\
\hline \multirow{4}{*}{$\begin{array}{c}\text { Glucose } \\
\text { Level } \\
\mathrm{mg} / \mathrm{dl}\end{array}$} & $100-150$ & $5(14.28 \%)$ & 3.82 & 51.26 \\
\cline { 2 - 5 } & $151-200$ & $13(37.14 \%)$ & 9.33 & 127.7 \\
\cline { 2 - 5 } & $201-250$ & $10(28.57 \%)$ & 6.28 & 111.9 \\
\cline { 2 - 5 } & $251-300$ & $5(14.28 \%)$ & 8.72 & 128.2 \\
\cline { 2 - 5 } & $301-350$ & $2(5.71 \%)$ & 3.17 & 139.4 \\
\hline \multicolumn{3}{|c|}{ LSD (Test groups and control) } & 4.05 & 55.8 \\
\hline
\end{tabular}

Among cross-sectional case study, the result (table 4) shows that 4-7 years duration of disease have higher percent $(40 \%)$ and lower percent $(8.57 \%)$ in 12 years. No differences in AIA and GM-CSF level among these group of patients except that the longer duration diabetes patient $(>12$ years) shows that highly reduced AIA in controversial with higher level of GM-CSF in comparison with other groups.

Table (4). Concentration ( $\mathrm{pg} / \mathrm{ml})$ of Anti insulin antibody and GM-CSF among different duration (years) of disease(D.M)

\begin{tabular}{|c|c|c|c|c|}
\hline \multicolumn{2}{|c|}{ Groups } & No. (\%) & Anti Insulin Ab. & GM-CSF \\
\hline \multirow{4}{*}{$\begin{array}{c}\text { Duration } \\
\text { (Year) }\end{array}$} & $1-3$ & $6(17.14 \%)$ & 9.9 & 77.4 \\
\cline { 2 - 5 } & $4-7$ & $14(40.0 \%)$ & 8.11 & 103.5 \\
\cline { 2 - 5 } & $8-11$ & $12(34.28 \%)$ & 6.32 & 128.7 \\
\cline { 2 - 5 } & $>12$ & $3(8.57 \%)$ & 2.74 & 300 \\
\hline \multicolumn{3}{|c|}{ LSD ( Test groups ) } & 3.38 & 102.5 \\
\hline
\end{tabular}

The result of AIA and GM-CSF level of diabetic patients according to disease type as shown in table (5), it is show that no differences in AIA level among both IDDM or type 1 and NIDDM or type 2, but type 2 shows the lowest concentration than type 1. The GM-CSF levels shows that the female patients infected with type 1 has lower level than male patients as well as the type 1 patients group have decreased GM-CSF level than type 2, although both groups are below the control level.

Table (5). Anti insulin Ab. and GM-CSF concentration levels among gender case study and two type of Diabetes

\begin{tabular}{|c|c|c|c|c|c|}
\hline \multicolumn{3}{|c|}{ Groups } & No. $(\%)$ & $\begin{array}{c}\text { Anti } \\
\text { Insulin }\end{array}$ & $G M-C S F$ \\
\hline \multirow{6}{*}{ Type } & \multirow{3}{*}{ IDDM (1) } & Male & $5(14.28 \%)$ & 9.79 & 104.8 \\
\hline & & Female & $3(8.57 \%)$ & 6.9 & 39.8 \\
\hline & & Total & $8(22.85 \%)$ & 8.34 & 72.3 \\
\hline & \multirow{3}{*}{$\begin{array}{c}\text { NIDDM } \\
\text { (2) }\end{array}$} & Male & $15(42.85 \%)$ & 7.7 & 100.4 \\
\hline & & Female & $12(34.28 \%)$ & 4.2 & 163.8 \\
\hline & & Total & $27(77.15 \%)$ & 5.9 & 132.2 \\
\hline \multicolumn{4}{|c|}{ LSD (Test groups and control) } & 3.6 & 60.3 \\
\hline
\end{tabular}

\section{Discussion}

Surendar et al. [15] reported that diabetes subjects have a wide range of cytokine values. The could be several reasons for these variations: (1) The diabetes population included both obese and lean diabetes subjects, and it is well known that the immune profiles in these two groups are different. (2) All the diabetes subjects were receiving treatment, and hence differences in the treatment modalities could also account for these wide variations. (3) Finally, the duration of diabetes, and it is well known that the duration of diabetes can in fact affect the cytokine profile. Our study, cross-sectional study revealed non significant differences decreasing in serum GM-CSF levels as compare with control group where as high increasing significant differences in serum AIA. This result confirm with our data differ from many study where the GM-CSF decreasing in DM subjects, this may be return to the epigenetic factor especially in some area than other. GM-CSF autocrine stimulation of myeloid cells is a key regulatory component in myeloid differentiation and activation responsiveness in mature monocytes and macrophages and is under strict temporal regulation. GM-CSF gene expression can be induced in myeloid cells by cytokines such as IL-6, IL-3, and IL-1 $\beta$, which induce epigenetic control modifications on its promoter [16]. the most of proinflammatory cytokines can affected by different kind of stress such as IL-6, and IL-1 $\beta$ [17], that finally can cause the GM-CSF decreasing or fluctuating secretion. Furthermore, our data indicate that decreasing GM-CSF secretion may be able to effects in the activation/differentiation in APC cells and support that immunosuppression in DM subjects. From our data we are suggested that GM-CSF can be use as co-treatment in diabetic patient, many study confirm this suggestion

Remesa and Rönnemaaa [18] shows the topically recombinant human GM-CSF healed the ulcers of young 
insulin-dependent diabetic patients suffering from chronic non healing leg ulcers of necrobiosis lipoidica diabeticorum were treated by applying macrophage GM-CSF on the ulcer repetitively during 10 weeks. Decrease in the size of the ulcers in diabetic patient was indicate the GM-CSF insufficient as compare with control group. Fang et al [19] also revealed that exogenous granulocyte-macrophage colony-stimulating factor (GM-CSF) is efficacious in the treatment of chronic wound healing in both animal models and patients, where, there was a significant reduction $(50 \%)$ in GM-CSF production in the wounds of the diabetics compared with non diabetics. The present study also shows the highly significant difference between Anti insulin $\mathrm{Ab}$ and GM-CSF, this reversely relationship also insurance of our suggestion that important of GM-SCF to developed the diabetic type 1 and type 2 complication Regardless of causes, where A number of proinflammatory cytokines/ chemokines including TNF, IL-1 and IL-6, MCP-1, and GM-CSF were well documented to involve in the pathogenesis of diabetes mellitus [20]. The current data, however, insure that GM-CSF plays an important role in increase or decrease anti insulin antibody especially in IDDM or NIDDM (Table 5). The a normal condition of cytokines secretion is recruit of macrophage, monocyte and antigenic presenting cells and lead finally to antibody secretion, then the cytokines (GM-CSF ) is decreasing. The significant differences in GM-CSF and AIA in IDDM or NIDDM in male and female in present study may be support the hypothesis that the female immune response more than male or may be related with lean or adipose tissue where, One hypothesis about the link between obesity and type II diabetes is that increased inflammation and cytokine secretion from adipose tissue leads to insulin resistance, particularly in the liver [21].

The current study conclude that, there is indirect relationship between AIA and GM-CSF level and that is mean increased AIA and glucose level reflect the reduced GM-CSF level among the diabetic patients may be used as biomarker or use GM-CSF as co-therapy with insulin.

\section{REFRENCES}

[1] Judkowski V. Krakowski M., Rodriguez E., Mocnick L., Santamaria P., Sarvetnick N. (2004). Increased islet antigen presentation leads to type-1 diabetes in mice with autoimmune susceptibility. Eur. J. Immunol. 34:1031-1040.

[2] Fleetwood A.J., Dinh H., Cook A.D., Hertzog P.J., Hamilton J.A. (2009). GM-CSF- and M-CSF-dependent macrophage phenotypes display differential dependence on Type I interferon signaling. Journal of Leukocyte Biology, $86: 411-421$

[3] Hamilton, J. A. (2008) Colony-stimulating factors in inflammation and autoimmunity. Nat. Rev. Immunol. 8, 533-544.

[4] Lari, R., Fleetwood, A. J., Kitchener, P. D., Cook, A. D.,
Pavasovic, D., Hertzog, P. J., Hamilton, J. A. (2007) Macrophage lineage phenotypes and osteoclastogenesiscomplexity in the control by GM-CSF and TGF- $\beta$. Bone 40 , 323-336.

[5] Fleetwood, A. J., Lawrence, T., Hamilton, J. A., Cook, A. D. (2007) Granulocyte- macrophage colony-stimulating factor (CSF) and macrophage CSF dependent macrophage phenotypes display differences in cytokine profiles and transcription factor activities: implications for CSF blockade in inflammation. J. Immunol. 178, 5245-5252.

[6] Inaba, K., Inaba, M., Romani, N., Aya, H., Deguchi, M., Ikehara, S., Muramatsu, S., Steinman, R. M. (1992) Generation of large numbers of dendritic cells from mouse bone marrow cultures supplemented with granulocyte/ macrophage colony-stimulating factor. J. Exp. Med. 176, 1693-1702.

[7] Jackson, S. H., Alicea, C., Owens, J. W., Eigsti, C. L., Malech, H. L. (2002) Characterization of an early dendritic cell precursor derived from murine lineagenegative hematopoietic progenitor cells. Exp. Hematol. 30, 430-439.

[8] Gordon, S. (2003). Alternative activation of macrophages. Nat. Rev. Immunol. 3, 23-35.

[9] Mantovani, A., Sica, A., Locati, M. (2005) Macrophage polarization comes of age. Immunity 23, 344-346.

[10] Castano, L. and Eisenbarth, G. S., (1990). Type-I diabetes: a chronic autoimmune disease of human, mouse, and rat. Annu. Rev. Immunol. 8: 647-679.

[11] Videbaek, N., Harach, S., Phillips, J., Hutchings, P., Ozegbe, P., Michelsen, B. K. and Cooke, A. (2003). An islet-homing NOD CD8+ cytotoxic T cell clone recognizes GAD65 and causes insulitis. J. Autoimmun. 20: 97-109.

[12] Bradley, B. J., Wang, Y. Y., Lafferty, K. J. and Haskins, K. (1990) In vivo activity of an islet-reactive T cell clone. J. Autoimmun. 3:449-456.

[13] Vanderlugt, C. J. and Miller, S. D. (1996). Epitope spreading. Curr. Opin. Immunol. 8: 831-836.

[14] King, C., Mueller Hoenger, R., Malo Cleary, M., MuraliKrishna, K., Ahmed, R., King, E. and Sarvetnick, N. (2001). Interleukin-4 acts at the locus of the antigen-presenting dendritic cell to counter-regulate cytotoxic $\mathrm{CD} 8+\mathrm{T}$ cell responses. Nat. Med. 7: 206-214.

[15] Surenda,J.; Mohan,V.; Pavankumar, N.; Babu, S.; and Vivekanandhan A.,V. (2012). Increased Levels of Serum Granulocyte-Macrophage Colony-Stimulating Factor Is Associated with Activated Peripheral Dendritic Cells in Type 2 Diabetes Subjects (CURES-99).Diabatic Technology \& Therapeutics, 14(4):343-349.

[16] Maton, B.R.; Elf, J.; Belkin, N.; Stutevoss, B.; Seydel, F.; Garrigan, E. and Litherland, S.A. (2008). M-CSF and GM-CSF Regulation of STAT5Activation and DNA Binding in Myeloid Cell Differentiation is Disrupted in Nonobese Diabetic Mice.Clinical and Developmental Immunology. Volume 2008, Article ID 769795, 8pages.

[17] Al-hassnawi, A.T.S. and Al-Quraishi, M.A. (2013). The Effects of Toxocara canis Infection With and Without Red light on the Levels of Melatonin Hormone and Cytokines Peripherial Blood of Albino Rat. J. Nat. Scie. Res., 3(9): 178-186. 
[18] Remesa, K. \& Rönnemaaa, T. (1999). Healing of Chronic Leg Ulcers in Diabetic Necrobiosis Lipoidica with Local Granulocyte-Macrophage Colony-Stimulating Factor Treatment. Journal of Diabetes and its Complications, 13(2): $115-118$.

[19] Fang, Y., Shen, J.; Yao, M.; Beagley, K.W.; Hambly, B.D and Bao, S. (2010). Granulocyte-macrophage colonystimulating factor enhances wound healing in diabetes via upregulation of proinflammatory cytokines. British J. Dermatol., 162(3): 478-486.

[20] Lee, I.; Hsieh, C.J.; Chen, R.; Yang, Z.; Wang, L.; Chen, C.;
Liu, C.F.; Huang, C.; Lin, C.; Chen, Y.; DYang, K. and Liu, J. (2013). Increased Production of Interleukin-4, Interleukin-10, and Granulocyte-Macrophage ColonyStimulating Factor by Type 2 Diabetes' Mononuclear Cells Infected with Dengue Virus, but Not Increased Intracellular Viral Multiplication. BioMed Research International, Volume 2013, Article ID 965853, 7pages.

[21] Kim, D.; Sandoval, D.; Reed, J., A.; Matter, E., K.; Tolod, E.,G.; Woods, S.,C. and Seeley, R., J.(2008). The role of GM-CSF in adipose tissue inflammation. Am. J. Physiol. Endocrinol. Metab.295: 1038-1046. 